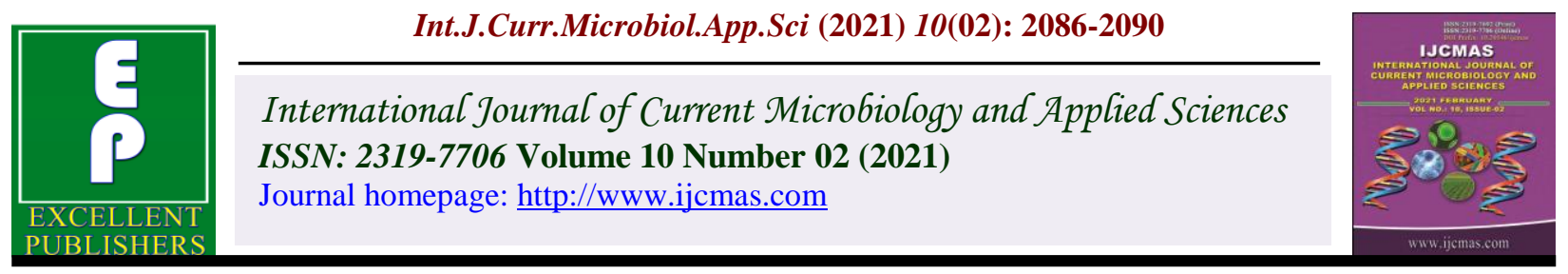

Original Research Article

https://doi.org/10.20546/ijcmas.2021.1002.248

\title{
Influence of Pre-Sowing Treatments on Germination, Growth and Vigour of Mango (Mangifera indica cv. Seeripazham)
}

\author{
V. Gopi ${ }^{1^{*}}$ and J. Samruban ${ }^{2}$ \\ Department of Horticulture, Faculty of Agriculture, Annamalai University, India \\ *Corresponding author
}

Keywords

$\mathrm{GA} 3, \mathrm{KNO}_{3}$,

Germination,

Mango, Whole nut,

Extracted kernel

Article Info

Accepted:

17 January 2021

Available Online:

10 February 2021

\section{A B S T R A C T}

An experiment was conducted in Annamalai Nagar, Tamil Nadu, India, to determine the effect of pre-sowing treatments on germination, growth and vigour of mango during 2017-2018. The various growth regulators viz., $\mathrm{GA}_{3}(250$ and $500 \mathrm{ppm}), \mathrm{KNO}_{3}(0.5$ and $1.0 \%)$, water soaking, control were treated before sowing the mango stones. Significantly higher values for all growth attribute parameters were recorded with the treatment $\left(S_{2} T_{3}\right)$ i.e extracted kernel pre-treated with $\mathrm{KNO}_{3} @ 0.5$ percent found to be sound integrated practice, were it recorded maximum germination percentage $(81.02 \%)$, number of leaves (12.92), vigour of seedling (1775.12) over all the other treatments. Whereas maximum seedling height $(31.51 \mathrm{~cm})$ intermodal length $(9.80 \mathrm{~cm})$ was recorded in extracted kernel pre-treated with $\mathrm{GA}_{3} @ 500$ ppm.

\section{Introduction}

Mango (Mangifera indica) was selected for the study as it is one of the most important fruits as the national fruit of India. India is the leading producer of mango in the world, while Tamil Nadu is the largest producer of mango with an annual production of 785.50 Metric tonnes from an area of 161.58 thousand ha, and productivity of 4.86 Metric tonnes per ha in the year of 2013-2014 (National Horticulture Board). Mango is predominantly grown as a cash crop nutritional value per
$100 \mathrm{~g}$ fruits is $250 \mathrm{KJ}$. Mango contains a variety of phyto chemicals (Ajila and Prasada, 2008.

In mango fruit pulp the vitamins " $\mathrm{A}$ and $\mathrm{C}$ " vitamin $\mathrm{B}_{6}$ pyridoxine, folate, other " $\mathrm{B}$ " vitamins and essential nutrients such as potassium, copper, and amino acids are present. Mango peel and pulp contain other phyto nutrients, such as the pigment antioxidants - carotenoids and polyphenols and omega- 3 and 6 poly unsaturated fatty acids (USDA, 2010). 
India as witnessed an increase in the area under mango on account of demand for fresh fruits in the domestic as well as the international market.

However, the greatest bottleneck in the expansion of area under fruit crops is the nonavailability of genuine and quality planting material in adequate quantity from reliable nurseries.

Health and good quality plant materials are the foundation for successful fruit industry in the country (Reddy and Shukla, 2007).

Synchronization and rapid seedling emergence are the commonly reported benefits of presowing treatments on germination. In most of the fruit crops, rootstock influences the vigour, longevity, tree size, yield and quality (Mukherjee and Majumdar, 1963).

The rootstock is a very vital component of a grafted plant and once the trees are grafted on a certain rootstock and planted in the orchard it is not possible to change it without incurring losses.

To meet the ever rising market demand and to evolve a best technology for producing high quality mango planting material in a short period of time pre-sowing treatments are very important which will also regulate growth and vigour of the rootstock organized research work in these lines of mango is not available and hence. The pre present research work has been designed.

\section{Materials and Methods}

The experiment was carried out in the year of 2017-2018 at orchard of the Department of Horticulture, Faculty of Agriculture, Annamalai University, Annamalai Nagar in India. The experiment was laid out in Factorial Randomized Block Design with six treatments by choosing two factors - seed material (whole nut and extracted kernel) and presowing treatments $\left(\mathrm{GA}_{3} @ 250\right.$ and 500 ppm), $\mathrm{KNO}_{3}(0.5$ and $1.0 \%)$ water soaking and control.

\section{Treatment details}

$\mathrm{S}_{1} \mathrm{~T}_{1}$ : Whole nut pre-treated with Gibberellic acid @250ppm for 12 hrs

$\mathrm{S}_{1} \mathrm{~T}_{2}$ : Whole nut pre-treated with Gibberellic acid @ 500ppm for 12 hrs

$\mathrm{S}_{1} \mathrm{~T}_{3}$ : Whole nut pre-treated with Potassium nitrate@ $0.5 \%$ for 12 hrs

$\mathrm{S}_{1} \mathrm{~T}_{4:}$ Whole nut pre-treated with Potassium nitrate@1.0\% for 12 hrs

$\mathrm{S}_{1} \mathrm{~T}_{5}$ : Whole nut soaked in water for $12 \mathrm{hrs}$

$\mathrm{S}_{1} \mathrm{~T}_{6}$ : Control (Whole nut without any treatment)

$\mathrm{S}_{2} \mathrm{~T}_{1}$ : Extracted kernel pre-treated with Gibberellic acid @ 250ppm for 12 hrs

$\mathrm{S}_{2} \mathrm{~T}_{2}$ : Extracted kernel pre-treated with Gibberellic acid @ 500ppm for 12 hrs

$\mathrm{S}_{2} \mathrm{~T}_{3}$ : Extracted kernel pre-treated with Potassium nitrate @ 0.5\% for 12 hrs

$\mathrm{S}_{2} \mathrm{~T}_{4}$ : Extracted kernel pre-treated with Potassium nitrate @ 1.0\% for 12 hrs

$\mathrm{S}_{2} \mathrm{~T}_{5}$ : Extracted kernel soaked in water for 12 hrs

$\mathrm{S}_{2} \mathrm{~T}_{6}$ : Control (Extracted kernel without any treatment)

The soil media was prepared by using red soil, well rotten farmyard manure (FYM) and sand in the proportion of $1: 1: 1$. Polythene bag with 
a size of $7 \times 9$ inches and 300 gauge thickness were used for sowing of mango stones. Polythene bags were filled with $2 / 3^{\text {rd }}$ of the potting mixture and mango stones are covered with $1 / 3^{\text {rd }}$ of the potting mixture. The polythene bags were watered immediately after sowing and at regular intervals.

Observations were recorded on germination percentage, number of leaves, vigour of seedling, seedling height, intermodal length at 60 days after sowing. All the observations were recorded by selecting five plants randomly from each replication.

The germination percentage was calculated using the formula at 60 days of sowing (Stephen, 2008).

Germination percentage

$=\frac{\text { Number of stones germinated }}{\text { Number of stones sown }} \times 100$

The vigour of the seedling was calculated using the following formula at 60 days of sowing (Kumar et al., 2007).

Vigour of the seedling $=$ Dry weight of the root stock $\times$ germination percentage

\section{Results and Discussion}

Statistically analyzed results are described and explained under the following subheads.

\section{Germination characters}

The data on germination percentage by presowing treatments in mango cv. Seeripazham was presented in table 1. Extracted kernel pre treated with $\mathrm{KNO}_{3} 0.5 \%$ found to be sound integrated practice, where it recorded maximum germination percentage $(81.02 \%)$.

Lower concentrations of potassium nitrate had significantly influenced the germination percentage. The variation in germination in pre-sowing osmoprimed stones might be due to stimulate effect of $\mathrm{KNO}_{3}$ on the stones as well as enhanced enzymatic process and suppression inhibitors along with synthesis of RNA, which might have resulted in maximum germination percentage (Kumar et al., 2007).

Extracted kernel recorded maximum germination percentage followed by whole nut. It might due to the removal of outer thin leathery seed coat probably increased the water absorption and might have lead to activate enzymes, hydrolysis of food material and resulted in maximum germination percentage.

The results are in conformity with the findings of Reddy and Khan (2001) in khirni, Rajamanickam et al., (2002) in Amla and Shirol et al., (2005) in khirni.

\section{Vigour characters}

Among the pre-sowing treatments studied $\mathrm{KNO}_{3} \quad 0.5 \%$ recorded maximum vigour of seedling (1775.12) followed by $\mathrm{GA}_{3}$ and water soaking. All the osmopriming treatments increased the seedling dry weight as compared to control.

Choudary and Chakrawar (1981) stated that the increase in number of leaves and root length had lead to overall assimilation and redistribution of photosynthates with in the plant and resulted in higher dry weight has the significant and there by increased the vigour of seedling similar results were reported Padma and Reddy and Khan (2001) in khirni, Raw et al., (2002) in mango.

\section{Growth characters}

Extracted kernel pre-treated with $\mathrm{GA}_{3} 500 \mathrm{ppm}$ recorded maximum seedling height and intermodal length. Rapid accumulation of food materials in this tissue results in obtaining maximum seedling height. 
Table.1 Effect of pre-sowing treatments on germination, growth characters and vigour characters of mango

\begin{tabular}{|c|c|c|c|c|c|c|c|c|c|c|c|c|c|c|c|}
\hline \multirow[t]{3}{*}{ Treatment(T) } & \multicolumn{3}{|c|}{ Germination \% } & \multicolumn{3}{|c|}{ Number of leaves } & \multicolumn{3}{|c|}{ Seedling height } & \multicolumn{3}{|c|}{ Intermodal length } & \multicolumn{3}{|c|}{ Vigour of mango } \\
\hline & \multicolumn{3}{|c|}{ Seed materials(S) } & \multicolumn{3}{|c|}{ Seed materials(S) } & \multicolumn{3}{|c|}{ Seed materials(S) } & \multicolumn{3}{|c|}{ Seed materials(S) } & \multicolumn{3}{|c|}{ Seed materials(S) } \\
\hline & $\begin{array}{l}\text { Whol } \\
\text { e nut }\end{array}$ & $\begin{array}{l}\text { Extracte } \\
\text { d kernel }\end{array}$ & mean & $\begin{array}{l}\text { Whol } \\
\text { e nut }\end{array}$ & $\begin{array}{c}\text { Extract } \\
\text { ed } \\
\text { kernel }\end{array}$ & mean & $\begin{array}{l}\text { Whol } \\
\text { e nut }\end{array}$ & $\begin{array}{l}\text { Extracte } \\
\text { d kernel }\end{array}$ & Mean & $\begin{array}{l}\text { Whol } \\
\text { e nut }\end{array}$ & $\begin{array}{l}\text { Extracte } \\
\text { d kernel }\end{array}$ & $\underset{\mathbf{n}}{\mathrm{mea}}$ & $\begin{array}{c}\text { Whole } \\
\text { nut }\end{array}$ & $\begin{array}{l}\text { Extracte } \\
\text { d kernel }\end{array}$ & Mean \\
\hline $\mathbf{G A}_{3} 250 P P M$ & 57.21 & 65.61 & 61.4 & 9.07 & 9.89 & 9.48 & 23.05 & 26.69 & 24.87 & 8.54 & 10.43 & 9.48 & 789.9 & 990.98 & 887.9 \\
\hline $\mathrm{GA}_{3} 500 P P M$ & 60.31 & 71.26 & 65.78 & 9.76 & 10.23 & 10.0 & 24.12 & 31.51 & 27.81 & 9.35 & 9.80 & 9.58 & 859.2 & 1135.15 & 997.20 \\
\hline $\mathrm{KNO}_{3} \mathbf{0 . 5 \%}$ & 65.59 & 81.02 & 73.31 & 10.53 & 12.92 & 11.72 & 22.94 & 25.08 & 24.01 & 8.59 & 9.47 & 9.03 & 1142.8 & 1775.12 & 1459.00 \\
\hline KNO3 1.0\% & 63.21 & 74.71 & 68.96 & 10.10 & 11.18 & 10.64 & 21.88 & 24.37 & 23.12 & 7.35 & 8.58 & 7.96 & 984.69 & 1356.38 & 1170.53 \\
\hline Water soaking & 54.85 & 63.45 & 59.15 & 8.13 & 9.73 & 8.93 & 19.24 & 23.96 & 21.60 & 6.39 & 7.65 & 7.29 & 700.40 & 827.58 & 763.99 \\
\hline control & 50.91 & 61.46 & 56.19 & 7.63 & 9.13 & 8.38 & 19.94 & 22.80 & 20.97 & 6.86 & 6.51 & 6.44 & 549.28 & 704.53 & 626.90 \\
\hline \multirow[t]{2}{*}{ mean } & 58.68 & 69.58 & & 9.20 & 10.51 & & 21.73 & 25.73 & & 7.85 & 8.74 & & 836.9 & 1131.62 & \\
\hline & $\mathbf{S}$ & $\mathbf{T}$ & $\mathbf{S} \times \mathbf{T}$ & $\mathbf{S}$ & $\mathbf{T}$ & $\mathbf{S} \times \mathbf{T}$ & $\mathbf{S}$ & $\mathbf{T}$ & $\mathbf{S} \times \mathbf{T}$ & $\mathbf{S}$ & $\mathbf{T}$ & $\mathbf{S} \times \mathbf{T}$ & $\mathbf{S}$ & $\mathbf{T}$ & $\mathbf{S} \times \mathbf{T}$ \\
\hline SE $\mathbf{m} \pm$ & 0.19 & 0.32 & 0.46 & 0.10 & 0.17 & 0.25 & 0.19 & 0.34 & 0.48 & 0.09 & 0.16 & 0.22 & 15.05 & 26.06 & 36.86 \\
\hline CD 5\% & 0.39 & 0.68 & 0.96 & 0.30 & 0.52 & 0.73 & 0.41 & 0.71 & 1.01 & 0.19 & 0.33 & 0.46 & 31.15 & 53.96 & 76.31 \\
\hline F-test & $*$ & $*$ & $*$ & $*$ & $*$ & $*$ & $*$ & $*$ & $*$ & $*$ & $*$ & $*$ & $*$ & $*$ & $*$ \\
\hline
\end{tabular}


Higher concentrations of $\mathrm{GA}_{3}$ had significantly influenced the seedling height with $\mathrm{GA}_{3}$ might be attributed to the cell multiplication and cell elongation in the cambium tissue of the intermodal region. $\mathrm{GA}_{3}$ all the concentrations used in the study, resulted in longer shoots with long and thin internodes. The results conformity with grape fruit seedlings elongation is a consequence of accelerated cell elongation rather than of cell multiplication. Rajamanickam et al.,(2004) in amla, Kumar et al., (2007) in mango.

The increase in number of leaves might be due to the promotion of physiological processes and stimulatory action of $\mathrm{KNO}_{3}$ to form new leaves at faster rate accelerated translocation of food material in the tissue which created an ideal condition for development of new leaf primordia. Similar results were reported by Bhambota and Kaul (1966) in citrus. These results are in conformity with the results reported by Padma and Reddy (1998) in mango.

\section{References}

Bhambota, J.R. and Chakrawar, V.R. (1966). Studies on the effects of gibberellic acid on growth of seedlings of citrus rootstocks. Indian J.Agric.Sci., 51(3):
201-203.

Kumar, Y.H., Swamy, G.S.K., Patil, C.P., Kanamadi, V.C. and Prasad Kumar (2007). Effect of pre-sowing treatments on germination, growth, vigour index and vigour of rootstocks in Mango. J. Asian Hort., 3(3):157161.

Mukherjee, S.K., and Mujumdar, P.K. (1963). Standardization of rootstock of mango and studies on propagation of clonal rootstocks by stooling and layering. Indian J.Hort., 20:204-209.

Padma,M. And Reddy, N.Y. (1998). Effect of pre-sowing treatments of stones and kernels on mango (Mangifera indica L.) germination. J. Res. ANGRU, 26(2):17-21.

Rajamanickam, C., Anbu, S.and Balakrishnan, K. (2002). Effect of chemicals and growth regulators on seed germination in aonla. South Indian J. Hort., 50(1/3):211-214.

Reddy, B.M.C. and Shukla, S.K. (2007). Hand book of seed and planting material testing manuals. In: seed and planting material testing manual for subtropical fruit crops. Indian council of agricultural research, Krish Anusandham Bhvan-II, New Delhi, 14-16

\section{How to cite this article:}

Gopi, V. and Samruban, J. 2021. Influence of Pre-Sowing Treatments on Germination, Growth and Vigour of Mango (Mangifera indica cv. Seeripazham). Int.J.Curr.Microbiol.App.Sci. 10(02): 2086-2090. doi: https://doi.org/10.20546/ijcmas.2021.1002.248 